\title{
Aortic thrombosis in a dog with chronic lymphocytic leukemia
}

\author{
Angel Ripplinger ${ }^{1}(\mathbb{D})$ Ana Paula da Silva ${ }^{2}$ Mathias Reginatto Wrzesinski ${ }^{1}$ (D) \\ Dênis Antonio Ferrarin ${ }^{1}$ Marcelo Luís Schwab ${ }^{1}$ (D) Ricardo Pozzobon ${ }^{3}$ Mariana Martins Flores ${ }^{4}$ \\ Ruth Pamela Thompson ${ }^{4}$ Fabiana Mario $^{5}$ Alexandre Mazzanti ${ }^{6 *}$ (D)
}

\begin{abstract}
1Programa de Pós-Graduação em Medicina Veterinária, Universidade Federal de Santa Maria (UFSM), Centro de Ciências Rurais (CCR), Santa Maria, RS, Brasil.

${ }^{2}$ Clínica Médica de Pequenos Animais, Hospital Veterinário Universitário (HVU), Centro de Ciências Rurais (CCR), Universidade Federal de Santa Maria (UFSM), Santa Maria, RS, Brasil.

${ }^{3}$ Departamento de Clínica de Grandes Animais, Centro de Ciências Rurais (CCR), Universidade Federal de Santa Maria (UFSM), Santa Maria, RS, Brasil. ${ }^{4}$ Departamento de Patologia, Centro de Ciências da Saúde (CCS), Universidade Federal de Santa Maria (UFSM), Santa Maria, RS, Brasil. ${ }^{5}$ Residência Multiprofissional em Medicina Veterinária, Área de Diagnóstico por Imagem, Hospital Veterinário Universitário (HVU), Universidade Federal de Santa Maria (UFSM), Santa Maria, RS, Brasil.

${ }^{6}$ Serviço de Neurologia e Neurocirurgia, Hospital Veterinário Universitário (HVU), Departamento de Clínica de Pequenos Animais, Centro de Ciências Rurais (CCR), Universidade Federal de Santa Maria (UFSM), 97105-900, RS, Brasil. E-mail: alexamazza@yahoo.com.br. ${ }^{*}$ Corresponding author.
\end{abstract}

ABSTRACT: The aim of this report was to describe a case of aortic thrombosis (AT) secondary to chronic lymphocytic leukemia (CLL). Although, different types of neoplasms are described as possible causes of aortic thrombosis, CLL was not yet considered. The dog showed signs of lameness that worsened with exercise. The diagnosis of AT was made by ultrasound examination. The diagnosis of CLL was made by necropsy, which showed the presence of small lymphocytes with the appearance of mature lymphocytes in the bone marrow, spleen, liver and kidneys. The importance of including CLL in the possible causes of AT in dogs, in addition to the suspicion of AT in cases of neuromuscular disease, was highlighted.

Key words: canine, lymphoid leukemia, ischemic neuromyopathy, thrombus.

Trombose aórtica em cão com leucemia linfocítica crônica

RESUMO: O objetivo do presente relato é descrever um caso de trombose aórtica (AT) secundária a leucemia linfocítica crônica (LLC). Embora diferentes tipos de neoplasmas sejam descritos como possíveis causas de trombose aórtica, a LLC ainda não foi considerada. O cão mostrou sinais de claudicação que pioravam com o exercício. O diagnóstico de AT foi realizado por exame ultrassonográfico. O diagnóstico de LLC foi feito por necropsia, que mostrou a presença de pequenos linfócitos com aparência de linfócitos maduros na medula óssea, baço, figado e rins. Destaca-se a importância da inclusão da LLC nas possíveis causas de AT em cães, além da suspeita de AT em casos de doença neuromuscular.

Palavras-chave: caninos, leucemia linfoide, neuromiopatia isquêmica, trombo.

Lymphoid leukemia is the most common type of leukemia seen in dogs, with chronic lymphocytic leukemia (CLL) being the most frequently diagnosed and treated diseased in this species (NORTH \& BANKS, 2009). The CLL is a proliferation of mature-looking small lymphocyte neoplastic clones that manifests as marked persistent peripheral lymphocytosis (WORKMAN \& VERNAU, 2003).

Aortic thrombosis (AT) is a primary or secondary change to systemic diseases (WINTER \& BUDKE, 2017) and causes ischemic neuromyopathy as a consequence of partial or total obstruction of blood flow to one or both pelvic limbs due to the presence of a thrombus (GONÇALVES et al., 2008).
The etiologies behind the formation of this thrombus in dogs are diverse and include neoplasm, protein loss nephropathy and/or enteropathy, hypothyroidism, diabetes mellitus, hyper or hypoadrenocorticism, as well as corticosteroid administration (WINKLE et al., 1993; GONÇALVES et al., 2008; LAKEBAKAAR et al., 2012; WINTER e BUBKE, 2017). However, CLL has not yet been included in the list of neoplasms that predispose dogs to this condition. In humans, the risk of venous thrombosis is recognized in patients with CLL (WHITTLE et al., 2011) due to both hyperleukocytosis (CUKIERMAN et al., 2002) and the presence of prothrombotic factors related to neoplasms (CRESPO-SOLÍS, 2012). No reports of arterial thrombosis were reported in humans or other 
animal species secondary to CLL. Therefore, this report aimed to describe a case of aortic thrombosis secondary to chronic lymphocytic leukemia in a dog.

An 8-year-old castrated male Australian cattle dog was presented for clinical care, with a 45 day history of anorexia and vomiting. No changes were observed during the general clinical examination.

During the patient's follow-up examination, hematocrit values ranged from normal to mild regenerative anemia. Mild to moderate thrombocytopenia was also observed (from 51,000 lymphocytes $\mu \mathrm{L}$ to 153,000 lymphocytes $/ \mu \mathrm{L}$; reference 200,000-500,000 lymphocytes/ $\mu \mathrm{L}$ ) (RIZZI et al., 2010). According to RIZZI et al. (2010), the leukogram showed lymphocytosis with values ranging from 4,838 to 9,020 lymphocytes/ $\mu \mathrm{L}$ (reference $1,000-4,800$ lymphocytes $/ \mu \mathrm{L})$. Serum biochemistry showed consistently high serum creatinine (from 2.5 to $5.0 \mathrm{mg} / \mathrm{dL}$, normal range: $0.5-1.5 \mathrm{mg} / \mathrm{dL}$ ) and urea values (from 82 to $228 \mathrm{mg} / \mathrm{dL}$, normal range:
21-60 mg/dL) (KANEKO et al., 2008). However, the urinalysis and urinary creatinine protein ratio did not reveal proteinuria $(\mathrm{UPC}<0.2)$. Apart from these tests, electrolyte dosing (showing values that were in the reference range) and rapid tests were also undertaken for Ehrlichia sp., Anaplasma sp., Borrelia burgdorferi for antibodies, and Dirofilaria immitis for antigens. All the tests reported negative values.

Two days immediately following the initial evaluation, lameness was noted in the right pelvic limb (RPL), mainly post exercise. No ataxia was evident. There was a reduction in the conscious proprioception of the left pelvic limb (LPL) and complete absence in the RPL (Figure 1A). A decreased in the muscle tone was noted when the spinal segmental reflexes were tested and patellar and flexor reflexes in the RPL were absent. The other limbs revealed no changes. On epaxial palpation, the patient expressed neither signs of pain nor changes in the cutaneous trunk reflex. No changes were observed

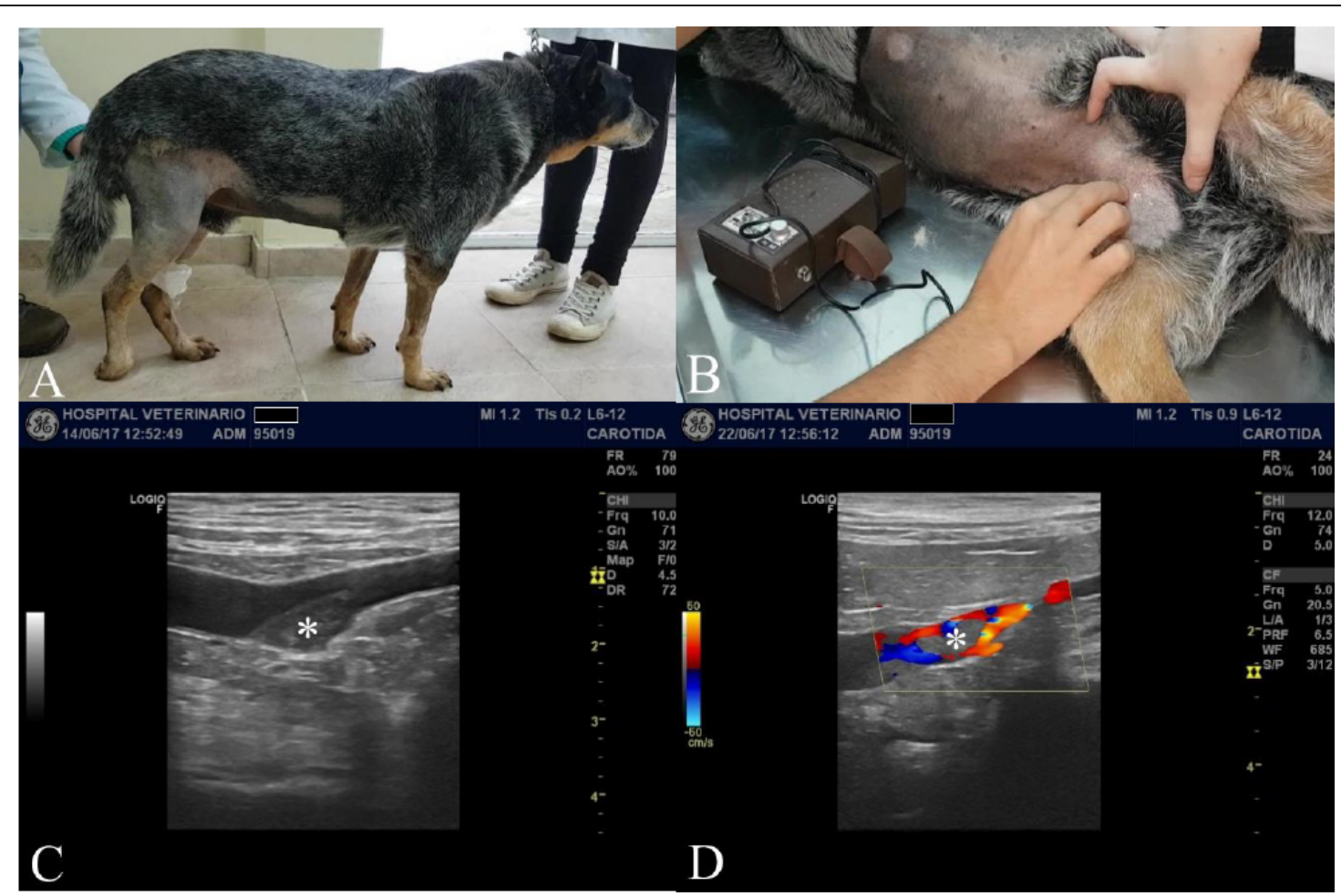

Figure 1 - Aortic thrombosis in a dog with chronic lymphocytic leukemia. 1A. Proprioceptive deficit of the right pelvic limb. 1B. Ultrasonic doppler for right femoral artery blood flow verification. 1C. Ultrasonography of the caudal abdominal aorta (near the trifurcation) and presence of a hyperechogenic mass $\left(^{*}\right)$, partially obstructing the vessel lumen, characterizing aortic thrombosis. 1D. Color doppler evaluation of the same site of Figure 1C, demonstrating partial blood flow. 
in the cranial nerve evaluation. No pulsation was noted on femoral artery palpation on the right side, and a decreased pulsation was noted on the left side. On performing an oscillometric Doppler evaluation, no sound was registered over the right femoral artery, and a reduction was noted on the left side (Figure 1B).

The alterations reported were classified as neuromuscular and the main clinical suspicion was ischemic neuromyopathy due to arterial flow obstruction to the right pelvic limb. Ultrasound examination revealed a hyperechogenic mass inside the caudal abdominal aorta that extended to the right femoral artery, partially obstructing the vessel lumen and characterizing aortic thrombosis (Figure 1C). On further evaluation of the same area using color Doppler, part of the blood flow appeared to be preserved (Figure 1D).

The diagnosis was AT and the patient started on intravenous heparin treatment $(100 \mathrm{IU} / \mathrm{kg}$, once every eight hours), as well as oral administration of acetylsalicylic acid $(0.5 \mathrm{mg} / \mathrm{kg}$, once every 12 hours). The patient did not present clinical or laboratory alterations consistent with any diseases that predispose to aortic thrombosis. Prothrombin time (PT: $11 \mathrm{~s}$ ) and activated tissue thromboplastin time (aPTT: $20 \mathrm{~s}$ ) were within normal ranges for the species (normal range PT 10-15 s and aPTT 10-20 s; LUBAS et al., 2010). In fact, five days after the commencement of treatment, the patient improved remarkably in terms of ambulation and neurological evaluation. However, as the nephropathy worsened, the owner decided in favor of euthanasia and a necropsy was performed.

At necropsy, thrombosis and aortic thromboembolism were evidenced. An irregular mass, "tan to dark red," was observed at the point where the aorta and internal iliac arteries bifurcated, which was focally adherent to the intimal layer of the vessel, occluding the lumen (Figure 2A). In the right internal iliac artery, a similar mass was identified. Histologically, this second thrombus revealed recanalization. In the left femoral artery, another firm mass was noted, fully adherent to the vessel, causing partial occlusion of the lumen. On the liver, whitish linear areas were visible on both the capsular and cut surfaces (Figure 2B). From a histological perspective,

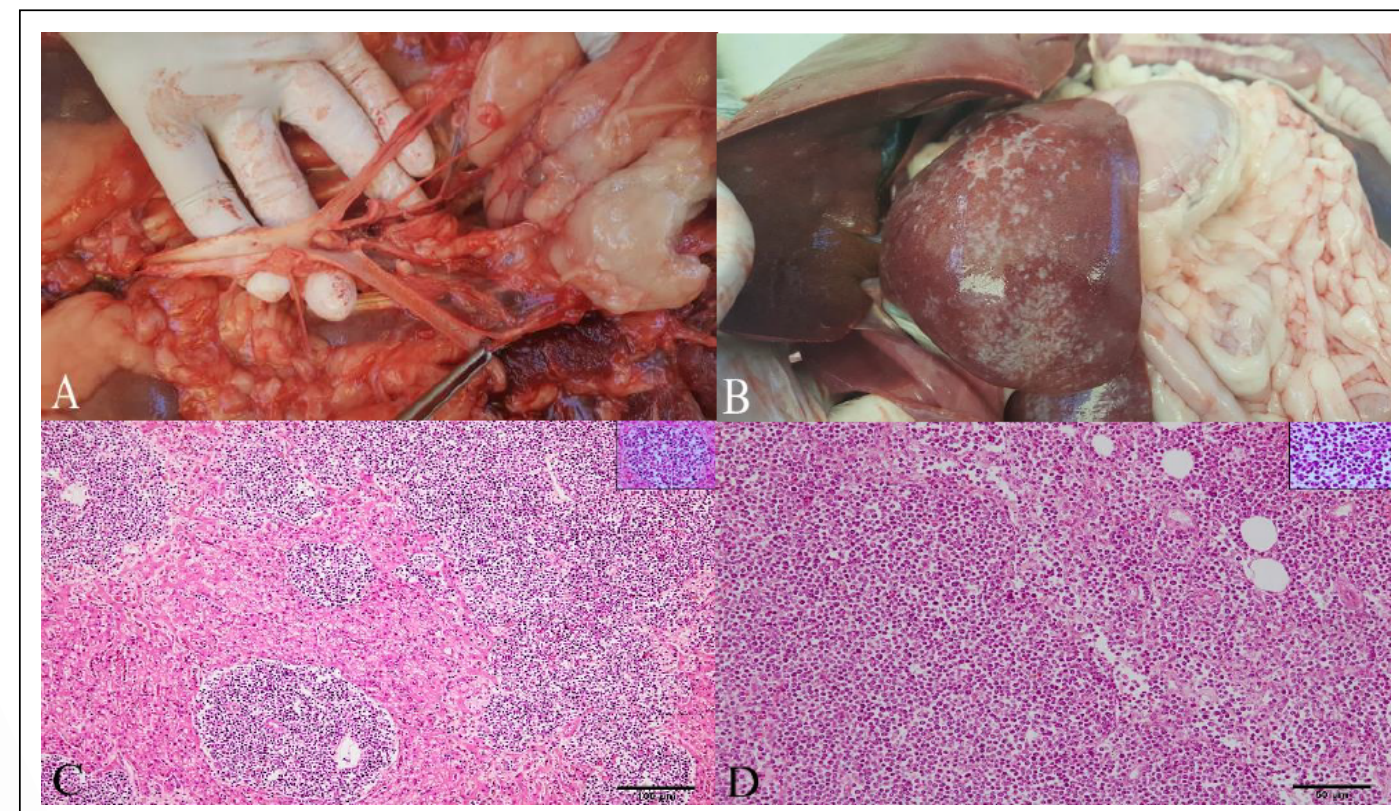

Figure 2 - Aortic thrombosis in a dog with chronic lymphocytic leukemia. 2A. Aortic artery, abdomen. A "tan to dark red", irregular mass (thrombus) is observed within the lumen of the aorta and external iliac arteries. $2 \mathrm{~B}$. Liver, metastasis of chronic lymphocytic leukemia. Multiple white linear areas are observed on the capsular surface. 2C. Liver, metastasis of chronic lymphocytic leukemia. The neoplastic cells are infiltrated around the centrolobular vein and portal tracts. Additionally, some of these cells are seen within the sinusoids. The cells are small and resemble mature lymphocytes (inset). Hematoxylin and Eosin (HE), Obj 20x, (inset, 40x). 2D. Bone marrow, chronic lymphocytic leukemia. A population of monomorphic round neoplastic cells resembling lymphocytes and similar to the cells observed within the liver infiltrates the bone marrow. Cells are small, with scarce cytoplasm (inset). HE, Obj 20x, (inset, 40x). 
the whitish areas on the liver appeared to be similar to the monomorphic infiltrates of the mature neoplastic lymphocytes encircling the centrilobular portal and vein triads and sometimes fully occupying the hepatic sinusoids (Figure 2C). An identical infiltrate was seen in the kidneys, spleen and multiple bone marrow sections, and in some regions, they almost completely replaced the medullary tissue (Figure 2D). Acute tubular necrosis was also identified. This was probably caused by leukemia. This is the most common cause of intrinsic acute kidney injury in lymphoma and leukemia reported in humans (LUCIANO \& BREWSTER, 2014).

Immunohistochemistry was performed in paraffin-embedded sections of the liver, kidney, and bone marrow to determine the origin of the neoplastic lymphocytes. The differentiation between $\mathrm{B}$ and $\mathrm{T}$ lymphocytes was done using anti-CD79 (Figure 3A) and anti-CD3 (Figure 3B) antibodies, respectively. Deparaffinization and rehydration of tissues were performed. For antigen retrieval, the slides were placed in a Tris-EDTA pH 9.0 buffer solution and heated for 10 minutes. Endogenous peroxidase blockage was performed with $3 \%$ hydrogen peroxide for 20 minutes. Blocking of nonspecific reactions was performed with $5 \%$ casein for 30 minutes at room temperature. As the primary antibodies, polyclonal anti-human CD3 antibodies (produced in rabbit) and monoclonal anti-human CD79 acy antibodies (produced in mice) were used. Antibodies were diluted in Tween phosphate-buffered saline (PBST) in the following ratio: 1:400 for anti-CD3 antibodies and 1:200 for anti-CD79 acy antibodies. After dilution, they were incubated at $37^{\circ} \mathrm{C}$ for 1 hour. Secondary antibody (polymer) was used consecutively, incubated at room temperature for 30 minutes and labeled by the addition of 3-3'-diaminobenzidine tetrachloride chromogen (DAB) for 5 minutes. Counterstaining was performed with Harris hematoxylin. A normal canine lymph node was used as a positive control. As a negative control, a section of tissue analyzed incubated with PBST alone was used. Immunohistochemical techniques complemented the diagnosis of chronic lymphocytic leukemia of B lymphocytes (Figure 3A).

AT is considered an uncommon disease in dogs (LAKE-BAKAAR et al., 2012; WINTER \& BUDKE, 2017). The clinical evolution of dogs with AT can be acute or chronic, and lameness, verified in the present case and sometimes intermittent (WINKLE et al., 1993; BOSWOOD et al., 2000) is often the first symptom to emerge. During exercise, the increased oxygen requirement of muscles in dogs with this condition cannot be satisfied because the arterial blood flow to the affected limb is totally or partially obstructed, which explains the association of worsening lameness with exercise, as confirmed in the patient in this study.

Clinical signs that mimic spinal cord dysfunction, such as monoparesis, paraparesis, or paraplegia may also be reported in cases of ischemic neuromyopathy (WINKLE etal., 1993; GONÇALVES et al., 2008). Other neurological alterations such as proprioceptive deficit in one or both pelvic limbs, as well as the reduction or absence of spinal segmental reflexes (BOSWOOD et al., 2000) are findings that may confuse the diagnosis of AT with lumbar spinal cord alterations (GONÇALVES et al., 2008).

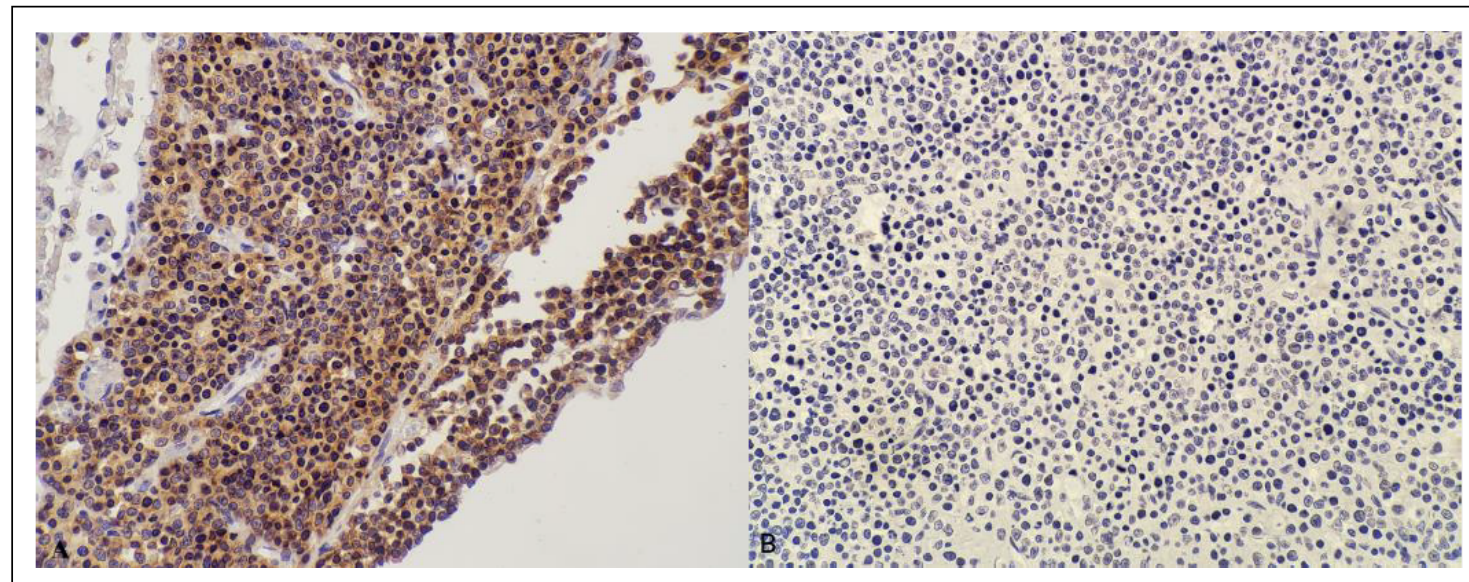

Figure 3 - Aortic thrombosis in a dog with chronic lymphocytic leukemia. 3A. Neoplastic lymphocyte immunoreactivity to CD79 (B cell positivity). Immunohistochemistry, $10 \mathrm{X}$. 3B. The neoplastic cells did not immunoreact with CD3 (T cell negativity). Immunohistochemistry, $10 \mathrm{X}$. 
Some pathological changes must occur for clot formation within a blood vessel, such as endothelial injury, blood flow changes or coagulability variations (WINKLE et al., 1993). Among neoplasms, carcinomas, adenocarcinomas, osteosarcoma, hemangiosarcoma, leiomyosarcoma, and lymphomas have been reported (WINKLE et al., 1993; BOSWOOD et al., 2000; GONÇALVES et al., 2008; LAKE-BAKAAR et al., 2012; WINTER \& BUDKE, 2017). However, this report is the first one linking AT to CLL.

The necropsy reports verified the diagnosis of AT by clinical and ultrasound testing and CLL was deduced by the distinctive features of the lymphocytes present in the histological analysis of the bone marrow which showed 40\% mature lymphocytes (LEIFER \& MATUS, 1985; WORKMAN \& VERNAU, 2003). Thus, it is assumed that the cause of AT in the present case is neoplastic; i.e., due to CLL.

While aortic thrombi in cats are commonly secondary to hypertrophic cardiomyopathy (ROBINSON \& ROBINSON, 2015), in dogs they are associated with several other underlying conditions such as neoplasia, chronic administration of corticosteroids and renal or cardiac disease (LAKEBAKAAR et al, 2012; WINTER et al., 2012). Frequently, the underlying cause of aortic thrombosis in dogs remains undetermined (WINTER et al., 2012). Another difference between aortic thrombi of dogs and cats is that thrombi generally form locally in dogs, which is called thrombosis (WINTER et al., 2012). The dog in this case report did not have any heart lesions on necropsy and histopathology examination, and no previous corticosteroid administration was reported by the owner. Chronic protein-losing nephropathies, including glomerulonephritis and renal amyloidosis, are the classical renal causes of thrombosis (RIZZI et al., 2010; LAKE-BAKAAR et al, 2012). They lead to antithrombin loss in the urine, which induces a hypercoagulable state (RIZZI et al., 2010). None of these renal diseases were seen in this case. Instead, a lymphoid neoplasia was observed infiltrating the liver and bone marrow. Based on the clinical history, the small number of organs affected by the tumor, and the disseminated distribution of the neoplastic cells within the bone marrow, a diagnosis of CLL with hepatic metastasis was established. A differential to be considered for CLL is small lymphocyte lymphoma but today it is already recognized that these two entities are different manifestations of the same disease and the designation of lymphoma or leukemia is made according to the tissue with the highest tumor burden (BOES \& DURHAM, 2017).
The CLL is conceptualized as a proliferation of small mature lymphocyte neoplastic clones and presents as persistent peripheral lymphocytosis (WORKMAN \& VERNAU, 2003). In the present case, peripheral lymphocytosis was mild, and the diagnosis of leukemia was post-mortem.

Clinical signs of CLL are variable and nonspecific (LEIFER \& MATUS, 1985) with generally asymptomatic canine patients (AVERY \& AVERY, 2007) unless they develop changes in other organs with the progression of the disease. When dogs showed clinical signs, the most commonly reported are lethargy, appetite reduction, and progressive weight loss (WORKMAN \& VERNAU, 2003). The clinical signs presented by the patient may be an association of CLL as well as the consequences of neoplastic infiltration in other organs.

The blood tests performed before death did not show any findings suggestive of myelophthisis, and there was no clinical suspicion of leukemia before necropsy was performed. This agrees with the clinical presentation of CLL, which is generally less aggressive (VALLI et al., 2015). Some authors explained the association between cancer and thrombosis by the release of procoagulant tumor products in the bloodstream, leading to increased clotting factor activation and enhanced platelet activity (KUMAR et al., 2013). Finally, lymphomas and leukemias seem to be some of the frequent neoplastic causes of thrombosis in dogs (LAKEBAKAAR et al., 2012).

In conclusion, dogs with exerciseworsening lameness who are suspected of having neuromuscular disease should be screened for differential diagnosis of ischemic aortic thrombosis, even if the signs are asymmetrical. Chronic lymphocytic leukemia should be included in the list of neoplasms that may predispose to aortic thrombosis in dogs.

\section{ACKNOWLEDGEMENTS}

We thank Coordenação de Aperfeiçoamento de Pessoal de Nível Superior (CAPES) for the Master and Doctorate research grants and Conselho Nacional de Desenvolvimento Científico e Tecnológico (CNPq) - process number 307120-2017-1.

\section{DECLARATION OF CONFLICT OF INTERESTS}

The authors declare no conflict of interest. The founding sponsors had no role in the design of the study; in the collection, analyses, or interpretation of data; in the writing of the manuscript, and in the decision to publish the results. 


\section{AUTHORS' CONTRIBUTIONS}

All authors contributed equally for the conception and writing of the manuscript. All authors critically revised the manuscript and approved of the final version.

\section{REFERENCES}

AVERY, A.C.; AVERY, P.R. Determining the significance of persistent lymphocytosis. Veterinary Clinics North America. Small Animal Practice, v.37, p.267-282, 2007. Available from: $<$ https://www.ncbi.nlm.nih.gov/pubmed/17336675>. Accessed: Jan. 20, 2019. doi: 10.1016/j.cvsm.2006.11.001.

BOES, K.M.; DURHAM, A.C. Bone marrow, blood cells, and the lymphoid/lymphatic system. In: ZACHARY, J. Pathologic Basis of Veterinary Disease. 6.ed. Elsevier. 2017, p.724-804.

BOSWOOD, A. et al. Aortic and iliac thrombosis in six dogs. Journal Small Animal Practice, v.41, n.3, p.109114, 2000. Available from: <https://www.ncbi.nlm.nih.gov/ pubmed/10759379>. Accessed: Feb. 10, 2019. doi: 10.1111/j.17485827.2000.tb03176.x.

CRESPO-SOLÍS, E. Thrombosis and acute leukemia. Hematology, v.17, sup.1, s169-s173, 2012. Available from: <https://www.ncbi. nlm.nih.gov/pubmed/22507812>. Accessed: Feb. 10, 2019. doi: 10 $.1179 / 102453312 X 13336169156852$.

CUKIERMAN, T. et al. Chronic lymphocytic leukemia presenting with extreme hyperleukocytosis and thrombosis of the common femoral vein. Leukemia and Lymphoma, v.43, n.9, p.1865-1868, 2002. Available from: <https://www.ncbi. nlm.nih.gov/pubmed/12685846>. Accessed: Feb. 10, 2019. doi: 10.1080/1042819021000006367.

GONÇALVES, R. et al. Clinical and neurological characteristics of aortic thromboembolism in dogs. Journal Small Animal Practice, v.49, n.4 178-184, 2008. Available from: <https://www. ncbi.nlm.nih.gov/pubmed/18339088>. Accessed: Dec. 10, 2018. doi: 10.1111/j.1748-5827.2007.00530.x.

KANEKO, J.J. et al. Appendix IX blood analyte reference values in small and some laboratory animals. In: . Clinical Biochemistry of Domestic Animals. 6.ed. Elsevier. 2008 , p.889-895.

KUMAR, V. et al. Hemodynamic disorders, thromboembolism and shock. In: KUMAR, V. et al. Robbins Basic Pathology. 9. ed. Elsevier Saunders: Philadelphia. 2013, p. 86-97.

LAKE-BAKAAR, G.A. et al. Aortic thrombosis in dogs: 31 cases (2000-2010). Journal American Veterinary Medical Association, v.241, n.7, p.910-915, 2012. Available from: $<$ https:// www.ncbi.nlm.nih.gov/pubmed/23013504>. Accessed: Dec. 10, 2018. doi: 10.2460/javma.241.7.910.

LEIFER, C.E.; MATUS, R.E. Lymphoid leukemia in the dog - acute lymphoblastic and chronic lymphocytic leukemia. Veterinary Clinics North America. Small Animal Practice, v.15, n.4, p.723-739, 1985. Available from: <https://www.ncbi. nlm.nih.gov/pubmed/3875921>. Accessed: Jan, 10, 2019. doi: $10.1016 /$ s0195-5616(85)50032-7.

LUBAS, G. et al. Laboratory testing of coagulation disorders. In: WEISS, D.J.; WARDROP, K.J. Schalm's Veterinary Hematology. 6.ed. Wiley-Blackwell. 2010, p.1082-1100.

LUCIANO, R.L.; BREWSTER, U.C. Kidney involvement in leukemia and lymphoma. Advances in Chronic Kidney Disease, v.21, n.1, p.27-35, 2014. Available from: <https://www.ncbi. nlm.nih.gov/pubmed/24359984>. Accessed: Feb. 05, 2019. doi: 10.1053/j.ackd.2013.07.004.

NORTH, S.; BANKS, T. Tumors of the haemolymphatic system - leukaemia and related disorders. In:_. Introdution to Small Animal Oncology. Saunders Elsevier. 2009, p.226-236.

RIZZI, T.E. et al. Normal hematology of the dog. In: WEISS, D.J.; WARDROP, K.J. Schalm's Veterinary Hematology. 6.ed. WileyBlackwell. 2010, p.799-810.

ROBINSON, W.F.; ROBINSON, N.A. Cardiovascular system. In: MAXIE, M.G. Jubb, Kennedy \& Palmer's Pathology of Domestic Animals. 6.ed. Elsevier: St. Louis, Missouri. 2015, p.63-64.

VALLI, V.E.O. et al. Hematopoyetic system. In: MAXIE, M.G. Jubb, Kennedy \& Palmer's Pathology of Domestic Animals. 6.ed. Elsevier: St. Louis, Missouri. 2015, p.136.

WHITTLE, A.M. et al. Chronic lymphocytic leukaemia is a risk factor for venous thromboembolism. Leukemia Research, v.35, p.419-421, 2011. Available from: <https://www.ncbi.nlm.nih.gov/ pubmed/21156322>. Accessed: Feb. 05, 2019. doi: 10.1016/j. leukres.2010.11.011.

WINKLE, T.J. et al. Clinical and pathological features of aortic thromboembolism in 36 dogs. Journal Veterinary Emergency Critical Care, v.3, p.13-21, 1993. Available from: <https:// onlinelibrary.wiley.com/doi/abs/10.1111/j.1476-4431.1993. tb00099.x>. Accessed: Jan, 21, 2019. doi: 10.1111/j.14764431.1993.tb00099.x.

WINTER, R.L.; BUDKE, C.M. Multicenter evaluation of signalment and comorbid conditions associated with aortic thrombotic disease in dogs. Journal American Veterinary Medical Association, v.251, p.438-442, 2017. Available from: $<$ https://www.ncbi.nlm.nih.gov/pubmed/28763280>. Accessed: Jan. 20, 2019. doi: 10.2460/javma.251.4.438.

WINTER, R.L. et al. Aortic thrombosis in dogs: presentation, therapy, and outcome in 26 cases. Journal Veterinary Cardiology, v.14, n.2, p.333-342, 2012. Available from: <https:// www.sciencedirect.com/science/article/pii/S1760273412000549>. Accessed: Jan. 20, 2019. doi: 10.1016/j.jvc.2012.02.008.

WORKMAN, H.C.; VERNAU, W. Chronic lymphocytic leukemia in dogs and cats: the veterinary perspective. Veterinary Clinics North America. Small Animal Practice v.33, p.1379-1399, 2003. Available from: <https://www.vetsmall.theclinics.com/article/ S0195-5616(03)00120-7/fulltext $>$. Accessed: Jan. 20, 2019. doi: 10.1016/s0195-5616(03)00120-7. 